\title{
A vásárlói magatartás elemzése az élelmiszer- és üzletválasztást befolyásoló tényezők alapján
}

\author{
Szakály Zoltán - Popovics Péter - Szakály Márk - Kontor Enikő \\ Debreceni Egyetem
}

\section{A TANULMÁNY CÉLJA}

A tanulmány célja a hazai fogyasztók élelmiszervásárlási döntéseinek vizsgálata az élelmiszer- és üzletválasztást befolyásoló tényezők alapján.

\begin{abstract}
ALKALMAZOTT MÓDSZERTAN
Az élelmiszervásárlói magatartás jellemzőinek azonosítása érdekében egy országos reprezentatív 1002 fös fogyasztói kutatást bonyolítottunk le. Az egyes régiókban és a kijelölt településeken a véletlen séta elvét alkalmaztuk a megfelelő háztartás kiválasztásához. A felkeresett háztartásban lakó személyek közül a születésnapi kulcs módszer alkalmazásával választottuk ki az interjúra megfelelő személyt. Az adatfelvételek sztenderd kérdőív segítségével, személyes interjúk keretében a megkérdezettek lakásán készültek. Az adatok feldolgozása során a leíró statisztikán túl faktoranalízis alkalmazásával jellemeztük a fogyasztók gondolkodásmódját, illetve klaszterelemzéssel szegmenseket alakítottunk ki az üzletválasztást befolyásoló tényezők alapján.
\end{abstract}

\section{LEGFONTOSABB EREDMÉNYEK}

A fogyasztók döntő többsége számára még mindig a legfontosabb vásárlást befolyásoló tényező a kedvező ár/érték arány, a kiemelkedő élvezeti érték, valamint a családi szokásrend. A boltválasztás szempontjai igazodnak ezekhez a tényezőkhöz, kiegészülve a gyors és széleskörủ beszerzési lehetőségekkel. Ezeket a preferált előnyöket a hipermarketek és a diszkontok képesek biztosítani leginkább, de elsősorban a nemzetközi láncok népszerüek, a hazai áruházláncok pozíciói gyengébbek. A vizsgálat során négy klasztert sikerült azonosítani: Igényes és motivált vásárlók (44,7\%), Gyorsan és kényelmesen vásárlók (22,1\%), Akció- és árérzékenyek (19,8\%), Közömbösek (13,4\%). Az eredmények szerint az élelmiszer-vásárlás iránti érdeklödés erősödőben van, melyre a láncok üzlet- és termékpolitikájuk módosításával válaszolhatnak.

\section{GYAKORLATI JAVASLATOK}

Bár a vásárlói döntés inkább racionális, mint emocionális, valós vásárlási szituációban az érzelmek tudattalanul befolyásolják a döntést, ezért az emocionális kapcsolat kiépítése (márka, imázs, bolti atmoszféra) elengedhetetlen. Stratégiai szempontból fontos kihívás a hazai élelmiszerláncok vásárlói hatókörének bővítése. A nagyobb penetráció biztosításának feltételei: kényelmes, gyors vásárlási lehetőség, kedvező árszínvonalú, megfelelő mélységü és szélességü termékválaszték, a választékon belül a kereskedelmi márkák diverzifikált kiterjesztése. Az egyre tudatosabbá váló, involvált fogyasztók igényeihez igazodni kell a környezetbarát és egészségvédő termékkör bővítésével.

Kulcsszavak: élelmiszer- és üzletválasztás, kereskedelmi láncok, klaszterek, fogyasztói tudatosság

Köszönetnyilvánitás: A publikáció elkészítését az EFOP-3.6.2-16-2017-00003 számú projekt támogatta. A projekt az Európai Unió támogatásával, az Európai Szociális Alap társfinanszírozásával valósult meg.

DOI: 10.15170/MM.2020.54.KSZ.II.01 


\section{BEVEZETÉS INTRODUCTION}

Az elmúlt évtizedben a kiskereskedelem egyike volt a legnagyobb ütemben fejlődő gazdasági ágazatoknak, s ez a gyors növekedés magával hozta az egyre intenzivebbé váló versenyt az egyes kiskereskedelmi üzlettípusok, láncok között (Szakály és tsai 2019). A fogyasztók szokásai megváltoztak, az ár mellett számos további tényezőt figyelembe vesznek vásárláskor. A fogyasztók számára elsősorban a kényelem, a hatékonyság, és az élmény jelentik azokat a tényezőket, melyeket elvárnak egy üzlettől, és amelyek döntéseiket meghatározzák (Törőcsik 2017). A kiskereskedelmi ágazatnak további változásokkal kell szembenézni, elsősorban azzal, hogy a vevők mikor, hol és hogyan bonyolítják le vásárlásaikat. A szerzők kitérnek $a z$ élelmiszer-választás motivációira, illetve a boltválasztást meghatározó tényezökre, majd egy primer fogyasztói kutatás eredményein keresztül mutatják be napjaink tendenciáit, rámutatva az azokban rejlő lehetőségekre és veszélyekre.

\section{IRODALMI ÁTTEKINTÉS LITERATURE REVIEW}

\section{Az élelmiszer-választást befolyásoló tényezők \\ Factors influencing food choice}

Szakály és társai (2018) egy 1050 fős lakossági mintán végzett kutatás alapján kimutatták, hogy a magyar fogyasztók számára az érzékszervi tulajdonságok, az ár, illetve a kényelmi faktorok a legfontosabbak egy élelmiszer kiválasztásakor. Elgondolkodtató eredmény, hogy a márka ismertségének, azaz a megszokásnak sokkal nagyobb a befolyásoló hatása Magyarországon, mint más kultúrákban. Ezt igazolja Markovina és társainak (2016) kilenc európai országra kiterjedő felmérése, melyből kiderül, hogy az ismertség az egyik legkevésbé fontos tényező más európai országban. Ugyanakkor az egészség szempontokat a magyarok veszik kevésbé figyelembe a szerb (Gagić et al. 2014), a finn (Roos et al. 2012), a belga, a román és a filippin (Januszewska et al. 2011) fogyasztókhoz képest.

A magyar fogyasztók egyre tudatosabban választanak élelmiszert, melyet egyértelműen jelez, hogy a minőség, az ár-érték arány és a származási hely a legfontosabb szempontok. Emellett a szavatossági időt, és a hazai alapanyagfelhasználást is figyelembe veszik, viszont a tetszetős csomagolás kevéssé befolyásolja őket (Termékmix 2018). Növekszik azon fogyasztók száma, akik információkat igényelnének a termékek eredetével, boltig vezető útjával kapcsolatosan (Nábrádi és tsai 2017). Ezt Füzesi és társai (2018) felmérése is alátámasztja, ahol a megkérdezettek $60 \%$-a értékelte fontosnak a termékek nyomonkövethetöségét. Ennek némileg ellentmond, hogy nagyon ritkán kerülnek felhasználásra azok az információforrások, ahol erről tájékozódni lehetne (a QR kód 6\%-os, a vonalkód 7\%-os, a kereskedők, gyártók honlapjai 8-9\%-os felhasználással bírnak). A legtöbben úgy gondolják, hogy a nyomonkövethetőség hatással van a termék minőségére és biztonságosságára, ezért drágábbak a konvencionális változatoknál. A potenciális fogyasztók 89\%-a nem fizetne többet a nyomonkövetési adatokért, és azok is, akik hajlandóságot mutatnak, maximum 1-10\%-kal magasabb árat tartanának elfogadhatónak (Füzesi és tsai 2018).

\section{Kiskereskedelmi áruházláncok látoga- tottsága, hatóköre Attendance and penetration of retail store chains}

A meglátogatott üzletláncok számának alakulása is jól követi a kereskedelem trendjeit. Míg 2017-ben a választás alapjául 2-3 üzletlánc szolgált, addig 2018-ban 3-4 üzletláncban vásárolt rendszeresen egy magyar fogyasztó (Edelshtein 2016, Kurucz 2018). Európában a legváltozatosabb üzletválasztási magatartást a dánok mutatták 4,5 lánccal, öket követték a németek és az osztrákok, egyaránt 3,9 lánccal (Kisari 2016). Általánosan elmondható, hogy a magyarok üzletválasztási magatartása rendkívül változékony volt az elmúlt években. Lojalitásuk egyáltalán nem nevezhetö stabilnak a láncok aktív lojalitásnövelő programjai ellenére. Amíg 2015-ben 11\% volt hü egy lánchoz, addig 2016-ra ez ugrásszerúen megnőtt 19\%-ra, majd 2017-ben ismét visszaesett 13\%-ra (Nielsen 2016, Kurucz 2018), ami egy kísérletező, összehasonlító vásárlási magatartásra utal.

$\mathrm{Az}$ élelmiszerbeszerzési szokások további változását jelzi, hogy a fogyasztók gyakrabban vásárolnak hétköznapokon, sokan a heti nagybevásárlás helyett másnaponta, vagy akár naponta is betérnek egy-egy boltba (Kisari 2016). Átlagosan 29\%-kal nőtt a boltlátogatás gyakorisága, mely jelentős mértékben a diszkontok és a drogériák 50-50\%-os növekedésének köszönhető. Ezeket nagy lemaradással követik a tradicionális üzletek, a hiper- és szupermarketek (18, 16 és $12,5 \%$-os 
növekedés a látogatások számában) (Nielsen 2016, Kurucz 2018).

A hazai vásárlásokat illetően $a$ stratégia üzlettípusonként eltérő. Míg az 1-3 termékkategóriára szorítkozó, akcióktól független, gyors vásárlásokat a hazai láncok üzleteiben, addig a nagyobb bevásárlásokat inkább a diszkontokban (48\%), a hiper(48\%) és szupermarketekben $(40 \%)$ bonyolították le a fogyasztók 2016-ban (GfK MFR 2017).

Magyarországon a diszkont rendelkezett a legnagyobb vásárlói hatókörrel 2017. elsö felében, az átlagos kosárméretet tekintve pedig csak a hipermarket előzte meg. A diszkontüzletek nem csupán a leglátogatottabbak voltak, de forgalmuk átlagosnál nagyobb részét a magas jövedelemmel rendelkező háztartások adták. A diszkontok térnyerésének egyik legfőbb oka a kínálatukban megjelenő kereskedelmi márkák egyre növekvő aránya. Az élelmiszerek piacán a kereskedelmi márkák részesedése majdnem elérte a 30\%-ot 2018-ban, ami 10\%-os növekedés az elöző évhez képest (Kurucz 2018).

A hiper- és szupermarketek forgalmának javulása kevésbé a látogatások számának, hanem inkább a vásárlási intenzitás növekedésének köszönhetö, míg a diszkontok és a drogériák körében nőtt a kosárérték és a vásárlási gyakoriság is (GfK MFR 2017).

\section{Az üzletválasztást befolyásoló tényezök Factors influencing store selection}

A magyar vásárlók boltválasztási szokásait alakító faktorokat a Nielsen három alapvető csoportba sorolta. A kényelem, a hatékonyság és az ár azok a motivációs hajtóerők, melyek napjainkban meghatározzák a vásárlás szinhelyének a kiválasztását (Kurucz 2018). Már ezek a tényezők is jelzik, hogy a magyarok prioritásai változóban vannak. A Nielsen felmérésében megkérdezettek a boltválasztás szempontjai között elsőként a keresett árucikk folyamatos elérhetöségét fogalmazták meg, de fontos a kiemelkedö vásárlói élmény is. Nem meglepö, hogy a fogyasztók számára lényeges döntési szempont az alacsony ár és a jó ár-érték arány. További döntési kritérium a könnyủ és gyors tájékozódás az üzletekben, illetve az, hogy minden szükséges árut egy helyen tudnak beszerezni. A promóciókat továbbra is figyelemmel kísérik, ezért akár messzebbre is hajlandók elmenni. A kiváló ügyfélszolgálati élmény előbbre lépett az elöző évhez képest a nyolcadik helyre, ami jelzi, hogy a kereskedelmi egységeknek egyfajta szolgáltatópartnerré kell válniuk. Egyre nagyobb igény mutatkozik a kereskedelmi márkás termékek iránt, arányuk egyre növekvő a vásárlók kosarában. Felsorolták még a friss élelmiszerek könnyü elérhetőségét, amely akár determinálhatja is az üzletválasztást (Szűcs-Villányi 2017).

Földi (2012) szerint el lehet különiteni egymástól a napi és a nagybevásárlások üzletválasztási szempontjait. Napi bevásárlások esetén a leglényegesebb szempont, hogy az üzlet a lakóhelyhez közel helyezkedjen el, illetve az áru legyen friss. Nagybevásárlásoknál a széles választék egyértelmủ elvárás, a fiatalok kedvező áron szeretnének vásárolni, az idősebbek viszont az akciókat és a szolgáltatásokat keresik. A középkorúak nagy kiszerelésekben szeretnek vásárolni és preferálják a megfelelő parkolási lehetőségeket (Földi 2012).

\section{ANYAG ÉS MÓDSZER MATERIAL AND METHOD}

A vizsgált téma összefüggéseinek feltárása érdekében egy 1002 fős országos reprezentatív fogyasztói kérdőíves kutatást indítottunk 2019. áprilisában. Az egyes régiókban és a kijelölt településeken a véletlen séta elvét alkalmaztuk, amely teljes véletlenszerüséget biztosít a megfelelő válaszadók kiválasztásához. A felkeresett háztartásban lakó személyek közül a születésnapi kulcs alkalmazásával választottuk ki az interjúra megfelelő személyt. A minta véletlen hibája $\pm 1,9 \%-3,2 \%$.

$\mathrm{Az}$ adatfelvételek sztenderd kérdőiv segitségével, személyes interjúk keretében a megkérdezettek lakásán készültek. A megkérdezett által adott válaszokat a kérdezőbiztos írta be a kérdöívre. A tanulmányban a következő témaköröket dolgoztuk fel:

- Az élelmiszer-vásárlást befolyásoló tényezők.

- Kiskereskedelmi áruházláncok (értékesítési formák) látogatottsága (vásárlói hatókör).

- Az üzletválasztás szempontjai.

A leíró statisztikán túl faktorelemzés segítségével jellemeztük a fogyasztók gondolkodásmódját. A tényezőcsoportok reliabilitás vizsgálatához Cronbach-féle alfa értékeket számítottunk. Ezt követöen elvégeztük a fogyasztók szegmentációját klaszteranalizis segítségével az üzletválasztást befolyásoló tényezők alapján. A minta nagy elemszámára való tekintettel a K-közép módszert választottuk (Sajtos \& Mitev 2007), melynek során a klaszterközepek meghatározását az algoritmusra bíztuk. 


\section{EREDMÉNYEK \\ RESULTS}

\section{Az élelmiszer vásárlást befolyásoló tényezők elemzése Analysis of factors influencing food-purchase}

Az élelmiszer-vásárlói döntést befolyásoló tényezők alakulását az 1. táblázat foglalja össze.

1. táblázat: Az élelmiszer-vásárlást befolyásoló tényezők fontossága $\left(\mathrm{N}=902^{1}\right)$

Table 1. Importance of factors influencing food purchase $\left(\mathrm{N}=902^{1}\right)$

\begin{tabular}{|l|c|c|c|}
\hline \multirow{2}{*}{ Vásárlást befolyásoló tényező } & \multicolumn{3}{|c|}{ Statisztikai mutató } \\
\cline { 2 - 4 } & Átlag² & Szórás & $\begin{array}{c}\text { Relatív } \\
\text { szórás (\%) }\end{array}$ \\
\hline Az élelmiszer állandó minősége & 4,64 & 0,762 & 16,42 \\
\hline Minőségmegőrzési idő & 4,61 & 0,775 & 16,81 \\
\hline A termékhez kötődő ízek & 4,58 & 0,744 & 16,24 \\
\hline Az egész család szereti & 4,41 & 0,919 & 20,84 \\
\hline Az élelmiszerek kedvezö ára & 4,32 & 0,944 & 21,85 \\
\hline Nagy választék & 4,19 & 0,922 & 22,00 \\
\hline Megszokás & 4,12 & 0,960 & 23,31 \\
\hline Akciós ár & 4,11 & 1,001 & 24,36 \\
\hline Az élelmiszer egészségessége & 4,03 & 0,992 & 24,62 \\
\hline Az élelmiszer esztétikus csomagolása & 3,90 & 1,079 & 27,67 \\
\hline Az élelmiszert Magyarországon állították elö & 3,81 & 1,060 & 27,82 \\
\hline Az élelmiszer eredete egészen a termelőig nyomon követhetősége & 3,70 & 1,176 & 31,78 \\
\hline Az élelmiszer elóállítása környezetbarát módon történt & 3,58 & 1,207 & 33,72 \\
\hline Híres márka & 3,33 & 1,264 & 37,96 \\
\hline A kereskedő márkaneve & 3,31 & 1,156 & 34,92 \\
\hline Az élelmiszer reklámozottsága & 2,83 & 1,432 & 50,60 \\
\hline Az élelmiszer bio minősítésủ & 2,80 & 1,378 & 49,21 \\
\hline
\end{tabular}

${ }^{1}$ Csak az élelmiszert valamilyen gyakorisággal vásárlókat kérdeztük meg.

${ }^{2}$ 1-5 fokozatú skála, ahol az 1-es érték az egyáltalán nem fontos, az 5-ös a nagyon fontos minösités.

Forrás: saját szerkesztés

A fogyasztók számára a vásárlást befolyásoló tényezők közül a legfontosabbak a termék ún. belső és közvetlen tulajdonságai. Ilyen az élelmiszer állandó minősége, minőség-megőrzési ideje, kiváló íze és kedvező ára. E tényezők az élelmiszerbiztonsági, a gazdasági és az élvezeti szempontok közé sorolhatók. Fontos döntési faktor a családi szokás és megszokottság, amely a habituális tényezők szerepére hívja fel a figyelmet. Az élelmiszerek egészségtámogató funkciója viszonylag kedvező megítélést kapott, de még így is jelentősen elmarad a legjobb pozícióban lévő tényezőktől. Egy kicsit talán meglepő módon a termék magyar származása a lista második felében helyezkedik el, akárcsak a nyomonkövethetőség, az élelmiszerek környezetbarát módon történő elóállítása, a márkanév és a reklámozottság. 


\section{Kiskereskedelmi áruházláncok (értékesítési formák) látogatottsága Attendance of retail store chains (sales forms)}

A következő kérdés a különböző kiskereskedelmi üzletláncok és az egyéb értékesítési formák vásárlói hatókörét (penetráció) elemezte. A kérdés a következő volt: ,,Kérem, mondja meg, hogy a felsorolt üzletláncok (értékesitési formák) közül melyekben vásárolt legalább egyszer az elmúlt egy év során”. Az eredményeket a 2. táblázatba foglaltuk.

2. táblázat: Különböző áruházláncok és értékesítési formák vásárlói hatóköre (N=902)

Table 2. Penetration of different store chains and forms of sales $(\mathrm{N}=902)$

\begin{tabular}{|c|c|c|}
\hline \multirow{2}{*}{ Áruházlánc/értékesítési forma } & \multicolumn{2}{|c|}{ Vásárolt legalább egyszer egy évben (\%) } \\
\cline { 2 - 3 } & Igen & Nem \\
\hline Tesco & 77,3 & 22,7 \\
\hline Lidl & 76,0 & 24,0 \\
\hline Piac & 66,5 & 33,5 \\
\hline Spar & 59,9 & 40,1 \\
\hline Önálló kis élelmiszerbolt & 59,6 & 40,4 \\
\hline Penny market & 58,6 & 41,4 \\
\hline Coop & 53,2 & 46,8 \\
\hline Aldi & 51,1 & 48,9 \\
\hline Interspar & 43,3 & 56,7 \\
\hline CBA & 41,0 & 59,0 \\
\hline Auchan & 39,3 & 60,7 \\
\hline Reál & 28,0 & 72,0 \\
\hline Metro & 23,2 & 76,8 \\
\hline Honiker & 14,5 & 85,5 \\
\hline
\end{tabular}

Forrás: saját szerkesztés

A felmérés eredményei szerint a Tesco és a Lidl foglalja el a legelőkelőbb pozíciót. A két áruházláncban a fogyasztók több mint 70\%-a vásárolt legalább egyszer az elmúlt év során. A piac töretlen népszerúségnek örvend a megkérdezettek körében, de $50 \%$ feletti penetrációs szinttel rendelkezik a Spar, az önálló kis élelmiszerbolt szegmens, a Penny Market, a Coop és az Aldi is. Elfogadható a helyzete az Intersparnak, a CBA-nak és az Auchannak is, ezekben az áruházakban a vásárlók 39-43\%-a fordul meg legalább egyszer egy év alatt. A sort a Reál, a Metro és a Honiker zárja. A Metro pozíciója a felsorolt áruházláncok sorában egyedi, mivel a többi kiskereskedelmi bolttípustól eltérően az üzletlánc az önkiszolgáló nagykereskedelemben tevékenykedik.

\section{Az üzletválasztás szempontjai Aspects of store selection}

A kutatási téma szempontjából lényeges kérdés, hogy a hazai fogyasztók milyen szempontokat vesznek figyelembe, amikor kiválasztanak egy áruházláncot vagy egy konkrét boltot. A válaszadóknak különböző boltválasztási szempontokat soroltunk fel, amelyeket egy 1-5 fokozatú fontossági skálán kellett értékelniük (1 - egyáltalán nem fontos; 5 - nagyon fontos). Az üzletválasztással kapcsolatos eredményeket a 3. táblázat mutatja be. 


\section{3. táblázat: Az üzletválasztást befolyásoló tényezők fontossága ( $(\mathrm{N}=902)$ \\ Table 3. Importance of factors influencing store selection $(\mathrm{N}=\mathbf{9 0 2})$}

\begin{tabular}{|l|c|c|c|}
\hline \multirow{2}{*}{ Üzletválasztást befolyásoló tényezö } & \multicolumn{3}{|c|}{ Statisztikai mutató } \\
\cline { 2 - 4 } & Átlag $^{\mathbf{1}}$ & Szórás & Relatív szórás (\%) \\
\hline A termékek megérik az árukat. & 4,55 & 0,799 & 17,56 \\
\hline Mindig kapható az, amire szükségem van. & 4,54 & 0,798 & 17,58 \\
\hline Mindent megkapok egy helyen. & 4,50 & 0,808 & 17,96 \\
\hline Gyorsan megtalálom, amire szükségem van. & 4,49 & 0,751 & 16,73 \\
\hline Kedvező az árszínvonal az üzletben. & 4,49 & 0,810 & 18,04 \\
\hline Vannak vonzó akciók, promóciók. & 4,41 & 0,863 & 19,57 \\
\hline Nincs zsúfoltság. & 4,26 & 0,880 & 20,66 \\
\hline A kiszolgálók kiváló szolgáltatást nyújtanak. & 4,26 & 0,902 & 21,17 \\
\hline Az üzlet közelsége. & 4,26 & 0,988 & 23,19 \\
\hline Vannak olcsó kereskedelmi márkás termékek. & 4,15 & 1,004 & 24,19 \\
\hline Vannak jó nevü gyártói márkák. & 4,08 & 0,983 & 24,09 \\
\hline Az üzletlánc jó híre. & 4,06 & 1,023 & 25,20 \\
\hline Kiváló parkolási lehetőség. & 3,81 & 1,454 & 38,16 \\
\hline A vásárlás élményt nyújt. & 3,66 & 1,179 & 32,21 \\
\hline
\end{tabular}

${ }^{1} 1$-5 fokozatú skála, ahol az 1-es érték az egyáltalán nem fontos, az 5-ös a nagyon fontos minösités. Forrás: saját szerkesztés

Jól látható, hogy a befolyásoló tényezők többsége fontos vagy nagyon fontos a válaszadók számára. A 4,40 feletti átlagértékek mindegyike a kedvező árhoz, a jó ár/érték arányhoz, illetve a gyors és széleskörü beszerzéshez kapcsolódik. Fontos szempont még a zsúfoltság elkerülése, a kiszolgálás színvonala, az üzlet közelsége, az üzletlánc jó híre, továbbá az alacsonyabb árszínvonalú kereskedelmi márkák és a híres gyártói márkák jelenléte a boltok polcain. Viszonylag alacsony fontossággal bír a jó parkolási lehetőség és az élményszerü vásárlás.

A vizsgálat során három faktort azonosítottunk, amelyek jól jellemzik a fogyasztók üzletválasztással kapcsolatos gondolkodásmódját (Extrakciós módszer: Maximum Likelihood; Rotációs módszer: Varimax Rotation; $\mathrm{KMO}=0,901$; Bartlett: (Approx. Chi Sq.) 4140,149; (Sig.) 0,000; Kumulatív magyarázott variancia: 55,659\%). Az első faktorba tömörülnek az árral és a gyors és széleskörü beszerzéssel kapcsolatos tényezők, ezért a faktort jellemzői alapján az ár és gyorsaság elnevezéssel illettük (magyarázott variancia: $38,704 \%$ ). A második tartalmazza az imázshoz kapcsolódó szempontokat. Ebben a gondolkodási keretben együtt jelenik meg az élményszerủ vásárlás, a márkák és a bolt hírneve, továbbá a kiszolgálás színvonala. A leírtak alapján a faktor a jó imázs megnevezést kapta (magyarázott variancia: 9,566\%). Úgy tünik, hogy a fogyasztói gondolkodásban együtt jelenik meg a zsúfoltság elkerülése és a jó parkolási lehetőség, amelyek a harmadik faktorba kerültek. A faktor a két befolyásoló tényező együttes jelenléte miatt a kényelem jelzőt kapta (magyarázott variancia: 7,400\%).

A szegmentáció végrehajtása előtt tesztelnünk kellett a modell alkalmasságát a további vizsgálatokra. A megbízhatóságot a Cronbach-féle alfa mutatóval (ár és gyorsaság: 0,822; jó imázs: 0,773 ; kényelem: 0,669) vizsgáltuk, melyek alapján az alkalmazott skáláink megbízhatónak tekinthetők. A következö lépésben a magyar fogyasztók szegmentálására került sor az üzletválasztást befolyásoló tényezők alapján, k-means klaszterezési eljárás alkalmazásával. Az eredményeket a 4. táblázatba foglaltuk. 


\section{4. táblázat: Fogyasztói klaszterek az üzletválasztást befolyásoló tényezők alapján Table 4. Consumer clusters based on factors influencing store selection}

\begin{tabular}{|c|c|c|c|c|c|c|c|c|}
\hline \multirow{3}{*}{$\begin{array}{l}\text { Üzletválasztást befolyásoló } \\
\text { tényezők }\end{array}$} & \multicolumn{8}{|c|}{ Statisztikai mutatók } \\
\hline & \multicolumn{2}{|c|}{$\begin{array}{c}\text { 1. klaszter } \\
(19,8 \%)\end{array}$} & \multicolumn{2}{|c|}{$\begin{array}{c}\text { 2. klaszter } \\
(22,1 \%)\end{array}$} & \multicolumn{2}{|c|}{$\begin{array}{c}\text { 3. klaszter } \\
(13,4 \%)\end{array}$} & \multicolumn{2}{|c|}{$\begin{array}{l}\text { 4. klaszter } \\
(44,7 \%)\end{array}$} \\
\hline & Átlag ${ }^{1}$ & Szórás & Átlag ${ }^{1}$ & Szórás & Átlag $^{1}$ & Szórás & Átlag ${ }^{1}$ & Szórás \\
\hline Mindent megkapok egy helyen. & 4,39 & 0,859 & 4,63 & 0,676 & 3,75 & 1,139 & 4,72 & 0,543 \\
\hline A vásárlás élményt nyújt. & 3,88 & 0,916 & 2,52 & 1,069 & 3,14 & 1,114 & 4,29 & 0,821 \\
\hline $\begin{array}{l}\text { Gyorsan megtalálom, amire } \\
\text { szükségem van. }\end{array}$ & 4,62 & 0,643 & 4,64 & 0,648 & 3,58 & 0,903 & 4,64 & 0,585 \\
\hline $\begin{array}{l}\text { Kedvező az árszínvonal } \\
\text { az üzletben. }\end{array}$ & 4,73 & 0,602 & 4,71 & 0,520 & 3,12 & 0,886 & 4,68 & 0,543 \\
\hline $\begin{array}{l}\text { Mindig kapható az, amire } \\
\text { szükségem van. }\end{array}$ & 4,51 & 0,819 & 4,76 & 0,630 & 3,52 & 0,971 & 4,75 & 0,519 \\
\hline $\begin{array}{l}\text { A kiszolgálók kiváló szolgáltatást } \\
\text { nyújtanak. }\end{array}$ & 4,38 & 0,771 & 3,93 & 0,949 & 3,32 & 1,041 & 4,66 & 0,555 \\
\hline Az üzletlánc jó híre. & 4,23 & 0,829 & 3,46 & 1,023 & 3,04 & 1,122 & 4,59 & 0,605 \\
\hline $\begin{array}{l}\text { Vannak olcsó kereskedelmi } \\
\text { márkás termékek. }\end{array}$ & 4,49 & 0,731 & 3,85 & 1,014 & 3,00 & 1,115 & 4,49 & 0,730 \\
\hline Vannak jó nevü gyártói márkák. & 4,10 & 0,914 & 3,45 & 0,997 & 3,35 & 1,044 & 4,60 & 0,593 \\
\hline Vannak vonzó akciók, promóciók. & 4,73 & 0,562 & 4,43 & 0,792 & 3,14 & 1,021 & 4,65 & 0,563 \\
\hline A termékek megérik az árukat. & 4,73 & 0,555 & 4,75 & 0,595 & 3,32 & 1,095 & 4,75 & 0,482 \\
\hline Az üzlet közelsége. & 3,92 & 1,152 & 4,55 & 0,717 & 3,41 & 1,157 & 4,53 & 0,750 \\
\hline Kiváló parkolási lehetőség. & 2,43 & 1,453 & 3,49 & 0,555 & 3,37 & 1,343 & 4,72 & 0,534 \\
\hline Nincs zsúfoltság. & 3,60 & 1,014 & 4,38 & 0,648 & 3,61 & 1,048 & 4,68 & 0,484 \\
\hline
\end{tabular}

1 1-5 fokozatú skála, ahol az 1-es érték az egyáltalán nem fontos, az 5-ös a nagyon fontos minösités; Szignifikancia vizsgálat (Post Hoc Test, Tukey, sig>0,05); N=902.

Forrás: saját szerkesztés

Az egyes klaszterek föbb jellemzői a következök (csak a statisztikailag szignifikáns különbségek jelennek meg a leírásban).

\section{1. klaszter: Akció- és árérzékenyek}

A csoport aránya 19,8\% (179 fö) a vizsgált populáción (902 fö) belül. A szegmensen belül enyhén felülreprezentáltak a nők (22,7\%), dominálnak az idős korosztályba tartozók (60 évesnél idősebbek $-20,6 \%)$, valamint a fiatalabbak (18-29 évesek - 21,5\%; 30-39 évesek - 20,1\%). A csoportban nagyobb arányban vannak jelen az általános iskolát végzettek (20,0\%) és a szakmunkások $(23,7 \%)$, míg az érettségizettek (16,9\%) és a diplomások $(17,4 \%)$ alulreprezentáltak. Jellemző a klaszterre az özvegyek $(27,7 \%)$, az elváltak (25,0\%) és a nyugdíjasok $(25,0 \%)$ dominanciája. Minél kisebb egy háztartás havi nettó jövedelme, annál fontosabb számára a kedvező árszínvonal, illetve a vonzó promóciók és akciók az üzletekben.

A klaszter tagjai számára kifejezetten fontos üzletválasztási szempont a boltok kedvezö árszínvonala, a jó vétel lehetősége. Fontosnak tartják, hogy alacsony áron vegyenek élelmiszereket, kifejezetten keresik a kereskedelmi márkás termékeket, illetve a promóciókat és akciókat. A felsoroltakkal szemben nem túl fontos számukra a kiváló parkolási lehetőség, a zsúfoltság mértéke a boltokban, de az üzlet közelsége sem.

2. klaszter: Gyorsan és kényelmesen vásárlók

Mérete alapján a második legnagyobb klaszter (22,1\%, 199 fö) a négy közül. A klaszterben felülreprezentáltak a férfiak (24,7\%), a 18-29 évesek 
(24,8\%) és a 60 évesnél idősebbek (27,3\%), továbbá a maximum nyolc általánost végzettek $(24,3 \%)$ és a szakmunkások (22,8\%). A csoportban dominálnak az özvegyek (30,1\%) és enyhén felülreprezentáltak a nőtlenek/hajadonok (23,1\%). A szegmensben az átlagosnál nagyobb arányban vannak jelen a nyugdíjasok $(27,7 \%)$ és a tanulók $(29,4 \%)$, a jövedelmi csoportok közül pedig az átlagos bevételü és az annál rosszabb anyagi helyzetben lévő háztartások. Az egyes településtípusok közül a budapestiek képviseltetik magukat a legnagyobb arányban $(24,4 \%)$, míg a kisebb városokban (20,2\%) és községekben élők (21,8\%) alulreprezentáltak.

A csoport tagjai számára kifejezetten fontos üzletválasztási szempont a gyorsaság, a szükségleteiknek megfelelő választék és a termékek állandó rendelkezésre állása, akárcsak az üzlet közelsége. A gyors és kényelmes beszerzést jellemzően összekapcsolják a jó vételi lehetőségekkel és a kedvezö árszínvonallal. Nem befolyásolja öket különösen az üzletlánc jó híre, a kiszolgálás színvonala, de a híres gyártói márkák jelenléte sem a boltok polcain.

\section{3. klaszter: Közömbösek}

A klaszter mérete alapján a legkisebb a 4 szegmens közül (13,4\%, 121 fó). A csoportban az átlaghoz közeli mértékben vannak jelen a nök és a férfiak $(13,1$, illetve $13,7 \%)$, miközben erősen felülreprezentáltak a 18-29 évesek (18,8\%), addig alulreprezentáltak a 60 évesnél idősebbek $(9,8 \%)$. Iskolai végzettség szerint dominálnak a maximum nyolc általánost végzettek (16,5\%). A különböző családi állapotú csoportok közül a legközömbösebbek a nőtlenek és a hajadonok $(19,7 \%)$, a foglalkozási csoportok közül pedig a tanulók (23,5\%). Erősen felülreprezentáltak a budapestiek (18,8\%), míg alulreprezentáltak a megyei jogú városokban élök $(9,4 \%)$.

A klaszter valamennyi üzletválasztást befolyásoló szempontot szignifikánsan alulértékeli föként az első és a negyedik csoporthoz képest.

\section{4. klaszter: Igényes és motivált vásárlók}

A csoport aránya a vizsgált populáción belül 44,7\%, azaz 403 fó, vagyis ez a legnagyobb klaszter. A szegmensben az átlaghoz közeli arányban jelennek meg a nök és a férfiak $(44,1$, illetve $45,4 \%)$, miközben felülreprezentáltak a 30-39 (53,7\%), a 40-49 (45,7\%) és az 50-59 évesek (49,3\%). A két szélső korcsoport, vagyis a 18-29 évesek, illetve a 60 évesnél idősebbek csak alacsony arányban vannak jelen a klaszterben $(34,9$, illetve $42,3 \%$ ). Az iskolai végzettség növekedésével párhuzamosan növekszik a klaszterbe tartozók aránya is (maximum nyolc általánost végzettek -
39,1\%; felsőfokú végzettségüek - 51,4\%). Jövedelmi szint szerint dominálnak a jobb anyagi viszonyok között élő háztartások. Igényes és motivált vásárlónak elsősorban a kisebb városokban élők nevezhetők (50,6\%), míg a Budapesten élők alulreprezentáltak $(36,9 \%)$.

A klaszterbe tartozók valamennyi üzletválasztást befolyásoló tényezőt felülértékelik. A csoport ellenpólusán a Közömbösek helyezkednek el, a két klaszter között minden esetben szignifikáns különbségek vannak.

\section{KÖVETKEZTETÉSEK ÉS JAVASLATOK CONCLUSIONS AND RECOMMENDATIONS}

A hazai fogyasztók többsége számára még mindig a legfontosabb vásárlást befolyásoló tényező a kedvezö ár/érték arány, a jó vétel lehetősége, a kiemelkedő élvezeti érték, valamint a családi szokásrend, amely alátámasztja az irodalmi előzményeket (Szakály és tsai 2018, Pólya 2019). Ezekért a szempontokért részben lemondanak az élelmiszer egészségességéről, környezetbarát jellemzőiről és magyar származásáról.

A Magyarországon jelenlévő diszkontláncokat - szemben a logikus elvárással - a jobb anyagi helyzetben lévő fiatalabb fogyasztók, és a magukat egészség- és környezettudatosnak vallók látogatják nagyobb gyakorisággal. Az eredmény megegyezik a GfK felméréseinek vonatkozó megállapításaival (GfK MFR 2017). A diszkontok (föként a Lidl és az Aldi) a kedvező ár mellett törekednek a kiváló minőség biztosítására, ami magában foglalja a modern fogyasztói trendeknek való megfelelést vagy a kényelmi, innovatív megoldások iránti igény kielégítését (Kisari 2016, Trade magazin 2019). A vezető diszkontokkal és a piacokkal kapcsolatos közös lakossági hiedelem a lokalitás, a frissesség, a környezetbarát és egészséges jelleg, valamint a nyomonkövethetőség. Ennek megfelelően az egészség- és környezettudatos fogyasztók mindkét csatornatípust előnyben részesítik a többivel szemben. A Coop kivételével a többi magyar áruházláncot az utolsók között említették meg, mint beszerzési forrást, vagyis pozíciójuk gyengébb, mint a nemzetközi hálózatoké. Stratégiai szempontból kihívás a hazai élelmiszer-kiskereskedelmi bolthálózatok vásárlói hatókörének javítása.

A boltválasztás szempontjai közül a kedvezö árhoz, a jó ár/érték arányhoz, illetve a gyors és széleskörü beszerzéshez kapcsolódó tényezők dominálnak. A vásárlók gyorsan szeretnének 
túljutni a beszerzés „fáradalmain”, miközben alacsony áron nagy választék mellett kívánják megvenni a szükséges élelmiszereket. Ezeknek a feltételeknek kiválóan megfelelnek a hipermarketek és a diszkontok, amelyek egy vagy több preferált előnyt képesek nyújtani. Nem véletlen, hogy mind a vásárlói hatókör, mind a heti vásárlási gyakoriság szempontjából is e két kategória prominens képviselői végeztek az első helyeken (Kisari 2016, Trade magazin 2019). Eredményeink alapján az üzletválasztást befolyásoló tényezők fontosság szerint három faktorba tömörülnek: ár és gyorsaság, jó imázs, kényelem. A Nielsen kutatásában ugyanezen tényezők jelennek meg, mint az üzletválasztásra vonatkozó motivációs hajtóerők (Kurucz 2018). Ennek alapján egy bolt akkor számíthat nagyobb penetrációra és kosárértékre, ha a vásárlókat kedvező áron, kényelmesen és gyorsan, megfelelő szélességü és mélységű termékválasztékkal szolgálja ki. Ennek része a kereskedelmi márkás termékek egyre szélesebb körü megjelenése is, melyeket a vásárlók egyre jobban szeretnek és igényelnek.

A fogyasztók szegmentálása alapján négy klasztert sikerült azonosítani, amelyek méretük szerint csökkenő sorrendben a következők: Igényes és motivált vásárlók (44,7\%), Gyorsan és kényelmesen vásárlók (22,1\%), Akció- és árérzékenyek (19,8\%), Közömbösek $(13,4 \%)$. A klaszterek elemzése alapján megállapítható, hogy az élelmiszer-vásárlás iránti érdeklődés erősödőben van. Ezt a tendenciát természetesen az áruházláncok is felismerték (egészségvédö és organikus élelmiszerek, helyi termékek, növényi alapú élelmiszerek egyre növekvő aránya a kínálatban). Az elkövetkező időszakban célszerü lehet az egyes klasztereket külön-külön is vizsgálni, ami mind piaci, mind tudományos szempontból további eredményekkel gazdagíthatja a szakterület ismeretanyagát.

\section{HIVATKOZÁSOK REFERENCES}

Edelshtein K. (2016), FMCG trendek a láncok toplistájának tükrében. https://www. nielsen.com/hu/hu/insights/article/2016/global-cci-hungarian-fmcg-retail-trends (letöltés: 2019.08.30.)

Földi K. (2012), A fogyasztói üzletválasztási döntések az élelmiszerorientált kiskereskedelemben. PhD értekezés, Pécsi Tudományegyetem Közgazdaságtudományi Kar

Füzesi I., Gyarmati Á., Lengyel P., Felföldi J. (2018), „Élelmiszer-jelölések hatása a fogyasztói döntésekre - különös tekintettel a nyomon követésre", Gazdálkodás, 62(5), 444458

Gagić, S., Jovičić, A., Tešanović, D. and Kalenjuk, B. (2014), "Motives for food choice among Serbian consumers", Economics of Agriculture, 61(1), 41-51 DOI: 10.5937/ekoPolj1401041G

GfK MFR (2017), Kereskedelmi hírlevél. 2(1), https:/www.gfk.com/fileadmin/user upload/ country_one_pager/HU/documents/GfK_Kereskedelmi_Hirlevel_20170525.pdf (letöltés: 2019.09.09.)

Januszewska, R., Pieniak, Z., and Verbeke, W. (2011), "Food choice questionnaire revisited in four countries. Does it still measure the same?", Appetite, 57, 94-98 DOI: 10.1016/j. appet.2011.03.014

Kisari É. (2016), Kategóriák nagy és kis boltokban. https://www.nielsen.com/hu/hu/insights/ article/2016/global-report-about-big-and-smallformats/ (letöltés: 2019.09.09.)

Kurucz P. (2018), „Hogyan vásárolunk nap mint nap - Az FMCG-vásárló - Nielsen Shopper Trends", A4C PROmo, Magyar Marketing Szövetség Konferenciájának előadása, Budapest, 2018. október 9.

Markovina, J., Stewart-Knox, B. J., Rankin, A., Gibney, M., de Almeida, M. D. V., Fischer, A., ... and Frewer, L. J. (2015), 'Food4Me study: Validity and reliability of food choice questionnaire in 9 European countries", Food Quality and Preference, 45, 26-32 DOI: 10.1016/j.foodqual.2015.05.002

Nábrádi Zs., Kovács S., Szakály Z. (2017), „A húsfogyasztási szokások összefüggése az evési attitüdökkel a fiatal felnőtt korosztályban", Marketing \& Menedzsment, 51(Különszám), $75-84$

Nielsen (2016), Boltválasztás: a vásárlás legyen kellemes élmény. https://www.nielsen.com/hu/ 
hu/insights/article/2016/shopper-trends-study/ (letöltés: 2019.09.09.)

Pólya, É. (2019), "The interrelationship between the factors influencing retail selection behavior and FMCG market network", Economica, 10(2), 77-62

Roos, E., Lehto, R. and Ray, C. (2012), "Parental family food choice motives and children's food intake", Food Quality and Preference, 24, 85-91 DOI: 10.1016/j.foodqual.2011.09.006

Sajtos L., Mitev A. (2007), SPSS kutatási és adatelemzési kézikönyv, Budapest: Alinea Kiadó

Szakály, Z., Kontor, E., Kovács, S., Popp, J., Pető, K. and Polereczki, Zs. (2018), "Adaptation of the Food Choice Questionnaire: the case of Hungary", British Food Journal, 120(7), 14741488 DOI: 10.1108/BFJ-07-2017-0404

Szakály Z., Kiss M., Kontor E., Fehér A., Kiss V., Kovács B. (2019), A hazai élelmiszer-kereskedelem helyzete, struktúrája és a marketing hatása a keresletre. OTP tanulmány, Debreceni Egyetem, Marketing és Kereskedelem Intézet, Debrecen

Szücs-Villányi Á. (2017), Fogyasztókra ható ingerek az üzlethelyiségekben. https://www. nielsen.com/hu/hu/insights/article/2017/ impulses-in-retail-environment/ (letöltés: 2019.08.31.)
Termékmix (2018), Élelmiszer vásárlásakor elsősorban a minőségre és az ár-érték arányra figyelnek a fogyasztók. http://termekmix.hu/kereskedelem/ kutatas/578-elelmiszer-vasarlasakor-elsosorban-a-minosegre-es-az-ar-ertek-aranyra-figyelnek-oda-a-megkerdezett-fogyasztok (letöltés: 2019.08.29.)

Törőcsik M. (2017), A kereskedelem új vonásai. Trendtanulmány. Dr. Törőcsik Marketing Inspiráció Fogyasztói Magatartás Kutató Intézet, Trendinspiráció Mühely, Pécs

Trade magazin (2019), A diszkontok a mindennapi bevásárlás helyszínévé váltak. https:// trademagazin.hu/hu/a-diszkontok-a-mindennapi-bevasarlas-helyszineve-voltak/ (letöltés: 2019.09.01.) 
Szakály Zoltán CSc, intézetigazgató egyetemi tanár szakaly.zoltan@econ.unideb.hu

Popovics Péter PhD, adjunktus popovics.peter@econ.unideb.hu
Szakály Márk, PhD hallgató szakaly.mark@econ.unideb.hu

Kontor Enikő PhD, adjunktus kontor.eniko@econ.unideb.hu

Debreceni Egyetem Gazdaságtudományi Kar

\section{Analysis of shopping behaviour based on factors influencing food choice and store selection}

\section{THE AIMS OF THE PAPER}

The aim of the study is to test the food shopping decisions of the Hungarian consumers based on factors that influence their food choice and store selection.

\section{METHODOLOGY}

To identify the features of the food shopping behaviour a representative nationwide research involving 1002 consumers was carried out. In each region and settlements the method of random walking was used to select the proper households. In each household birthday key method was used to identify the person who was suitable for the interview. The data collection was done with personal interviews using standard questionnaires in the respondents' home. During data processing besides descriptive statistics factor- and cluster analyses were used to characterise the consumers' way of thinking, or different segments were created based on the factors that influence the selection of the store.

\section{MOST IMPORTANT RESULTS}

For the majority of the consumers the most important factors influencing purchase are still the favourable price to value ratio, the outstanding sensory appeal, as well as the family traditions. It is the store selection viewpoints that adjust to these factors, complemented by the fast and wide purchasing possibilities. These preferred benefits can mainly be provided by the hypermarkets and discount stores, however, the multinational chain stores are more popular among the customers compared to the Hungarian ones, whose positions are weaker. During the research work four clusters were identified. They are the following: Ambitious and motivated shoppers (44.7\%), Fast and convenient shoppers (22.1\%), Sales and price sensitive shoppers (19.8\%), Neutrals (13.4\%). According to their analysis, the interest towards food-purchase is increasing and the grocery stores responded to this trend by modifying their product policies.

\section{RECOMMENDATIONS}

Although the shopping decisions are rather rational than emotional, in a real shopping situation the emotional factors also influence the shopping decision, which means that it is vital to build an emotional tie (brand, image, shopping atmosphere). From strategic view it means a great challenge to widen the consumer scope of the Hungarian chain stores. The conditions to ensure greater penetration are the comfortable and fast shopping facilities, reasonable prices, a wide range of the products, and within this, to increase the diversification of the private labels. The demands of the more conscious and involved consumers have to be met by increasing the range of environment friendly and health protective products.

Keywords: food- and store choice, retail chains, clusters, consumer consciousness

Acknowledgement: The publication is supported by the EFOP-3.6.2-16-2017-00003 project. The project is co-financed by the European Union and the European Social Fund. 